\title{
Combining Pharmacological Countermeasures to Attenuate the Acute Radiation Syndrome-A Concise Review
}

\author{
Michal Hofer *, Zuzana Hoferová, Daniel Depeš and Martin Falk \\ Department of Cell Biology and Radiobiology, Institute of Biophysics, v.v.i., Czech Academy of Sciences, \\ Královopolská 135, 61265 Brno, Czech Republic; hoferovaz@centrum.cz (Z.H.); blackburn@ibp.cz (D.D.); \\ falk@ibp.cz (M.F.) \\ * Correspondence: hofer@ibp.cz; Tel.: +420-541-517-171; Fax: +420-541-211-293 \\ Academic Editor: Diego Muñoz-Torrero \\ Received: 28 March 2017; Accepted: 16 May 2017; Published: 19 May 2017
}

\begin{abstract}
The goal of combined pharmacological approaches in the treatment of the acute radiation syndrome (ARS) is to obtain an effective therapy producing a minimum of undesirable side effects. This review summarizes important data from studies evaluating the efficacy of combining radioprotective agents developed for administration prior to irradiation and therapeutic agents administered in a post-irradiation treatment regimen. Many of the evaluated results show additivity, or even synergism, of the combined treatments in comparison with the effects of the individual component administrations. It can be deduced from these findings that the research in which combined treatments with radioprotectors/radiomitigators are explored, tested, and evaluated is well-founded. The requirement for studies highly emphasizing the need to minimize undesirable side effects of the radioprotective/radiomitigating therapies is stressed.
\end{abstract}

Keywords: acute radiation syndrome; radioprotectors; radiomitigators; combined treatment; cytokines

\section{Introduction}

Although the search for suitable radiation countermeasures for radiation-associated injuries was initiated more than half a century ago, very few safe and effective radiation countermeasures for the most severe of these injuries, namely acute radiation syndrome (ARS), defined as 'an acute illness caused by irradiation of the entire body (or most of the body) by a high dose of penetrating ionizing radiation in a very short period of time (usually a matter of minutes) [1], have been approved. This exception is represented by two granulocyte colony-stimulating factor (G-CSF)-based radiation countermeasures (Neupogen ${ }^{\circledR}$ and Neulasta ${ }^{\circledR}$ ) which have recently been approved by the United States Food and Drug administration (US FDA) for treatment of the hematopoietic ARS; both of these agents are radiomitigators for use after radiation exposure [1,2]. Not surprisingly both of the topics of "radioprotectors for use prior to exposure" and "therapeutic agents for post-exposure treatment" possess top priority among the research areas for radiological nuclear threat countermeasures [3].

It is well known that most of the agents tested for their abilities to protect from accidental radiation exposure or mitigate its health consequences, including the most effective ones, exhibit toxicities that can limit their usefulness. Therefore, various approaches have been used to decrease their undesirable side effects. One of the approaches is to combine two or more agents with the aim to reduce their toxicities while preserving, or even enhancing, the overall therapeutic outcome (e.g., $[4,5])$. This concise review deals with some of the most studied and promising experimental combinatory pharmacological interventions in ARS. The aim of the review is to emphasize the advantages of the approach of combined pharmacological treatment with radioprotectors/radiomitigators in patients with ARS. 


\section{Combinations Including Amifostine (WR-2721)}

Amifostine (WR-2721), the most important representative of thiol radioprotectors, is a powerful radioprotective agent (a drug for use prior to irradiation); it acts on the principle of chemical radioprotection, i.e., predominantly by decreasing the levels of reactive oxygen species and hydrogen peroxide (e.g., [5]). Amifostine has been reported to reduce the effect of a radiation dose by a factor of up to 2.7 (the highest dose reduction factor (DRF) seen in a mouse 30-day survival model) [6]. However, due to its rather high toxicity, amifostine has not been approved for the treatment of ARS; nevertheless, it has found its use in radio- and/or chemotherapy-treated oncological patients (especially in head-and-neck cancer) as a selective protector of normal cells (e.g., $[7,8]$ ). Ongoing studies on amifostine using modern methods have confirmed its advantageous therapeutic qualities (e.g., [9]) and, therefore, the research on the combined use of amifostine with other agents in the treatment of ARS is worth mentioning.

Much work has been done on evaluation of combined effects of amifostine and antioxidative salts of various metals, like copper, zinc, or selenium (summarized by Weiss et al. [10]), both administered in the pre-irradiation regimen. It is noteworthy that the radioprotective efficacy of the metal-containing compounds themselves has been found to be low, whereas they have been found to significantly enhance the protective effects of amifostine and other thiol radioprotectors and reduce the thiol toxicity (e.g., [10,11]). Several hypotheses have been proposed explaining how metal salts positively influence the metabolism of amifostine; e.g., alkaline phosphatase activity in bone marrow cells has been shown to be significantly depressed after treatment with selenium, suggesting that a retardation of conversion of amifostine to its active free sulfhydryl form through the action of alkaline phosphatase might be responsible for the effects of selenium [10]; selenium has also been reported to induce glutathione peroxidase activity [12]. These findings and considerations have been reflected in later clinical attempts combining selenium and amifostine to attenuate undesirable effects of oncological radio/chemotherapy $[13,14]$.

Another naturally-occurring antioxidant studied for the treatment of ARS in a combination with amifostine is vitamin E, a less effective radioprotector than synthetic thiols, like amifostine, but providing a longer window of protection against lethality (summarized by Weiss and Landauer [15]). In a 30-day survival experiment, WR-3689 (a thiol drug related to amifostine) and its combination with vitamin E (both administered pre-irradiation) have shown their DRFs of 1.35 and 1.49, respectively [16]. Later studies on rats' whole bodies irradiated with a dose producing ARS have revealed mutually potentiating action of amifostine and vitamin E on radiation-damaged liver [17]. Recent findings have confirmed and extended the data from previous studies: an important observation has been obtained regarding the possibility to use low, non-toxic doses of amifostine and $\gamma$-tocotrienol, a vitamin $\mathrm{E}$ family member, for obtaining a high level of radioprotection [18].

In a pre-radiation administration setting, amifostine has also been experimentally combined with prostaglandin $\mathrm{E}_{2}\left(\mathrm{PGE}_{2}\right)$ or its synthetic analog, misoprostol. In a 30-day survival study, the DRF of amifostine alone, $\mathrm{PGE}_{2}$ alone, and amifostine $+\mathrm{PGE}_{2}$ in combination has been found to be 1.9, 1.45, and 2.15, respectively [19]. Prostaglandins have been found to stimulate erythroid and multilineage progenitor cells [20], as well as to enhance homing of hematopoietic stem cells through upregulation of the chemokine receptor CXCR4 and to stimulate hematopoietic stem cell survival by upregulation of apoptosis protein Survivin [21]. Both $\mathrm{PGE}_{2}$ and misoprostol have been reported to also be effective in the intestinal radiation syndrome [22]. Much later findings on the protective role of amifostine in preventing gastric damage produced by the prostaglandin synthesis inhibitor indomethacin have confirmed a positive influence of amifostine on the metabolism of prostaglandins [23].

Immunomodulators represent a wide group of substances stimulating the immune/hematopoietic system. Many of them, e.g., $\beta$-glucan and Broncho-Vaxom, shown here as examples of immunomodulators suitable for combined administration with amifostine for the treatment of ARS, possess no, or low, toxicity and are often commercially available. Their mechanism of action enables them to be administered in both protective and therapeutic regimens. Beta-glucan, 
a polyglucose, has been isolated from various sources. Thus, $\beta$-glucan from Saccharomyces cerevisiae, administered post-radiation, has been shown to significantly enhance the radioprotective effects of pre-irradiation-administered amifostine, their DRFs in a survival study being 1.37, 1.08, and 1.52 for amifostine alone, $\beta$-glucan alone, and amifostine $+\beta$-glucan, respectively [24]. The triple combination of pre-irradiation-administered amifostine, selenium, and $\beta$-glucan has been also reported as a very successful multiple-agent radioprotector [25]. In 2013, Pillai and Devi [26] followed up these studies with their experiments using $\beta$-glucan from the mushroom Ganoderma lucidum; they have reported a $100 \%$ mortality in untreated mice, but a $66 \%$ survival rate after 8 Gy exposure and post-irradiation administration of $\beta$-glucan, and even higher survival (83\%) following the combination of pre-irradiation amifostine and post-irradiation $\beta$-glucan [26]. The authors stress that $\beta$-glucan is not toxic at the radioprotective dose [26]. For details on hematologic and radioprotective efficacy of $\beta$-glucan, see [27]. Broncho-Vaxom, a bacterial lysate, has been shown to potentiate in both protective and therapeutic administration settings the radioprotective effects of pre-irradiation amifostine [28,29]. The values of DRF in a survival study have been reported to be 1.92, 1.17, and 2.07 for amifostine alone, Broncho-Vaxom alone, and amifostine + Broncho-Vaxom, respectively, if both the drugs were applied pre-irradiation [29]. Recent studies on immunomodulators as components of drug combinations tested for their potential radioprotection/radiomitigation comprise polysaccharide from Sipunculus nudus and peptidoglycan. Polysaccharide from Sipunculus nudus, which is a species of unsegmented marine worms, administered post-irradiation jointly with interleukin-11 (IL-11) and G-CSF, has been reported to enhance the radioprotective action of pre-irradiation amifostine, as shown when parameters of hematopoietic, immune, and reproductive tissues in irradiated mice were evaluated [30]. Pre-irradiation amifostine and post-irradiation peptidoglycan, a polymer from the bacterial cell wall consisting of sugars and amino acids, have been found to synergistically promote the survival of irradiated mice through the amelioration of intestinal and bone marrow damage [31].

Granulocyte colony-stimulating factor (G-CSF) is a hematopoietic growth factor especially stimulating the production of neutrophils [32] and also showing antiapoptotic qualities [33]. For the detailed summary of its use in the treatment of ARS, see [34]. The combination of amifostine and G-CSF for the treatment of ARS has been aimed especially at evaluating the efficacy of the combined pre-irradiation amifostine and post-irradiation G-CSF therapy. In animal studies, this combination has been shown to be very effective [35,36], e.g., in a 30-day survival study, the LD50/30 values (radiation doses killing $50 \%$ of the experimental animals by day 30 after irradiation) for mice administered saline, G-CSF, amifostine, and amifostine + G-CSF have been reported to be 7.85 Gy, 8.30 Gy, 11.30 Gy, and $12.85 \mathrm{~Gy}$, respectively [35]. In later publications dealing with the use of the amifostine + G-CSF combination in oncological patients, this approach has been thoroughly discussed in connection with both chemotherapy [37] and radiotherapy [38].

Metformin, a biguanide drug used in the treatment of type II diabetes, administered in a single dose $24 \mathrm{~h}$ after irradiation, has been found to significantly potentiate the radioprotective effects of amifostine in several cell types [39]. Metformin has been proposed to reduce endogenous reactive oxygen species and/or to slow down cell renewal progression and, as a result, to increase the time for repair; it has been suggested as a potentially useful agent for radiation countermeasures use [39].

The chemical structures of the selected substances explored in Section 2, namely amifostine, vitamin E, WR-3689, prostaglandin $\mathrm{E}_{2}$, misoprostol, and metformin, are summarized in Figure 1. 
a) amifostine<smiles>NCCCNCCSP(=O)(O)O</smiles>

b) vitamin $E$

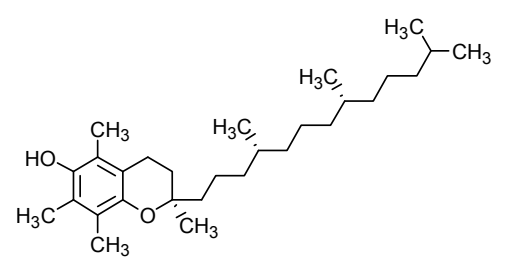

d) prostaglandin $\mathrm{E}_{2}$

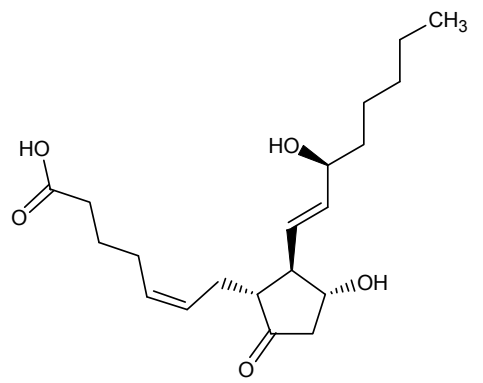

f) metformin

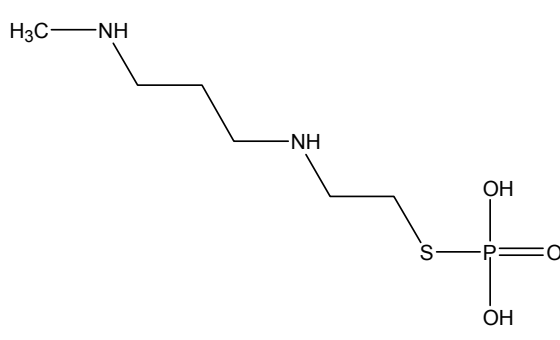

e) misoprostol

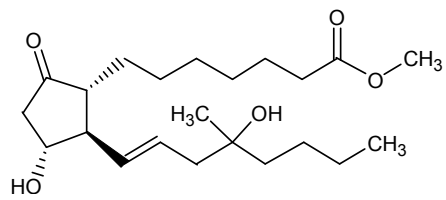<smiles>CN(C)C(=N)NC(=N)N</smiles>

Figure 1. Chemical structures of selected substances explored in Section 2.

\section{Combinations without Amifostine or Other Thiol Radioprotectors}

Whereas amifostine and related substances act in ARS mostly on the principle of chemical radiprotection (scavenging of free radicals), the combinations addressed in this paragraph include mostly agents functioning by influencing various metabolic and regulatory pathways in the mammalian organism. The latter agents have been often classified under the term "biological response modifiers" [40]. Their advantage is the possibility of both pre- and post-irradiation administration.

It has been found that the receptor action of extracellular adenosine acts radioprotectively in mice by the mechanisms of hypoxia induction due to the effects of the treatment on the cardiovascular system and enhanced regeneration of hematopoiesis; elevation of extracellular adenosine has been produced by combined administration of dipyridamole, a drug inhibiting the cellular uptake of adenosine, and adenosine monophosphate, an adenosine prodrug [41]. These findings and considerations have been confirmed in several studies and are summarized in a review [42]. Though not done on irradiated mice, the key for this topic were the results of a study describing the synergistic effects of combining dipyridamole + adenosine monophosphate with G-CSF on the production of neutrophils [43]; the effectiveness of this drug combination has been confirmed also under the conditions of ARS [44]. Later is was found that a selective stimulation of adenosine $\mathrm{A}_{3}$ receptors, e.g., by $N^{6}$-(3-iodobenzyl)adenosine- $5^{\prime}-N$-methyluronamide (IB-MECA), is responsible for the radioprotective and hematopoiesis-stimulating effects, previously observed after non-selective adenosine receptor 
activation, by the combination of dipyridamole and adenosine monophosphate [45]. Further experiments have shown that IB-MECA supports hematopoiesis-stimulating effects of G-CSF in sub-lethally irradiated mice when the two drugs are administered in a combination [46].

Cyclooxygenase inhibitors have been long studied for their ability to enhance hematopoiesis in an irradiated mammalian organism. With respect to their mechanism of action, they have been reported to remove, by inhibiting synthesis of $\mathrm{PGE}_{2}$, the negative feedback control of myelopoiesis played by $\mathrm{PGE}_{2}$ (for a detailed review, see [47]). Combined administration of diclofenac, a non-selective cyclooxygenase- 1 and cyclooxygenase- 2 inhibitor, and $\beta$-glucan, an immunomodulator, in single doses before irradiation of mice with a single sublethal dose of $\gamma$-rays, has been found to produce significantly better restoration of hematopoiesis in comparison with the mice administered with each of the drugs alone [48]. The same has become true when the two agents have been applied to mice before each of several repeated radiation doses [49]. When selective cyclooxygenase-2 inhibitors appeared, retaining the hematopoiesis-stimulating efficacy of non-selective cyclooxygenase inhibitors and producing less undesirable side effects, their representative, meloxicam, has been tested in a combined administration with IB-MECA, an adenosine $\mathrm{A}_{3}$ receptor agonist, in a post-irradiation regimen for the treatment of ARS. The combination of meloxicam + IB-MECA has been reported to be effective both when hematopoiesis was evaluated following a sub-lethal radiation dose [50] and when the survival of mice served as an outcome after a lethal radiation dose [51]. Meloxicam has also been found to stimulate endogenous production of G-CSF in irradiated mice [52] and to be able to substitute G-CSF in the treatment of ARS [53].

The abovementioned experimental combinatory ARS treatments including G-CSF represent only a part of the studies on the combined use of hematopoietic growth factors and cytokines in the treatment of the acute radiation disease. There exists a rather high number of papers on this topic already from the 1980s and 1980s. Some examples of these papers follow. As reported by Patchen et al., treatment of irradiated mice with the combination of $\beta$-glucan and G-CSF in a post-irradiation setting has been found to positively influence hematopoietic regeneration and survival of mice [54]. Enhanced radioprotection of mice has also been observed for the combinations of interleukin-1 (IL-1) and tumor necrosis factor [55] in a pre-irradiation therapeutic approach, IL-6 and G-CSF [56] administered after irradiation, or the triple combination of mast cell growth factor (C-kit ligand) + granulocyte-macrophage colony-stimulating factor (GM-CFC) + interleukin-3 (IL-3) also given post-irradiation [57]. Combination therapy of ARS using post-irradiation administration of G-CSF and synthokine SC-55494 (a synthetic high-affinity IL-3 ligand [58]) has been reported to be effective against post-irradiation neutropenia and thrombocytopenia in rhesus monkeys [59]. These experimental animals have also been used to evaluate the effects of the post-irradiation combinations of thrombopoietin (TPO), GM-CSF, and G-CSF; it has been stated that TPO significantly improves the performance of GM-CSF and G-CSF in alleviating severe neutropenia [60]. Significantly enhanced multilineage hematopoietic recovery in non-human primates has been observed following combined administration of megakaryocyte growth and development factor (MGDF) and G-CSF [61]. Intense attention has been paid to the topic of the post-irradiation administration of cytokine and growth factor combinations by the group of Hérodin and coworkers. Their experiments in mice have shown that the combinations of stem cell factor (SCF), Flt3-ligand, TPO, interleukin-3 (IL-3), and stromal-derived factor-1, administered 2 and $24 \mathrm{~h}$ after irradiation, significantly improved both short-term and long-term survival of the animals [62]. These findings have also been confirmed in subsequent studies on non-human primates where heavily irradiated (a whole-body dose of $7 \mathrm{~Gy}$ ) monkeys were reported to be successfully treated from a severe bone marrow radiation syndrome when administered one-time combinations of SCF + glycosylated erythropoietin (EPO) + pegylated G-CSF [31] or pegylated G-CSF $+\mathrm{SCF}+$ Flt3-ligand + TPO + IL-3 [63] very early $(2 \mathrm{~h})$ after irradiation. The authors propose, as the main therapeutic mechanism of these cytokine cocktails, their anti-apoptotic action and emphasize the necessity of the early post-irradiation application of the drugs ("the sooner the better" [64]). Studies on the combined pharmaceutical modulation of ARS manifestation by pharmacological combinations 
comprising hematopoietic growth factors and cytokines still continue: a recent study has evaluated the efficacy of the joint administration of EPO, G-CSF, c-mpl receptor agonist romiplostim (a fusion protein analog of TPO), and nandrolone decanoate (a synthetic androgen) in mice following either a single post-irradiation dose within $2 \mathrm{~h}$ after irradiation, or five doses in five days following irradiation, as the most efficacious combination of EPO, G-CSF, and romiplostim that has been appraised [65].

Combinations of hematopoietic growth factors and cytokines have already found their use in the treatment of radiological accident victims. Various combinations of G-CSF, GM-CSF, EPO, SCF, and IL-3 have been administered to victims of accidents in Soreq (Israel, 1990), Neshviz (Belarus, 1992), Henan Province (China, 1999), Tokaimura (Japan, 1999), Prakan (Thailand, 2000), Fleurus (Belgium, 2006), and Dakar (Senegal, 2006) (summarized in [66]). Differing outcomes of the individual treatments are difficult to evaluate due to differing radiation sources, exposure doses, and other circumstances of the accidents.

Various natural antioxidants also play a role in radioprotective/radiomitigating combinations, e.g., mutual potentiation of the effects of post-irradiation administration of quercetin, an antioxidative flavonoid, and indralin, an adrenomimetic, in mice has been reported [67]. Enhanced hematopoietic protection has been obtained by combined pre-irradiation administration of the isoflavone genistein, an antioxidant and protein kinase inhibitor modulating signal transduction pathways, and captopril, an angiotensin-converting enzyme and vasodilator [68]. The combination of tocopherol succinate (a hemisuccinate ester of $\alpha$-tocopherol belonging to the vitamin E family), an antioxidant, and AMD3100, an antagonist of chemokine receptor CXCR 4, enabling the displacement of hematopoietic stem cells and their subsequent migration to the peripheral blood, has been found to stimulate hematopoiesis in supralethally-irradiated mice [69]. Combined pre-irradiation administration of $\alpha$-tocopherol acetate (an agent from the vitamin E family) and ascorbic acid (vitamin C), both antioxidants, has been reported to produce radioprotective properties, as shown by reduction of the numbers of chromosome aberrations in the bone marrow of rats [70]. A mixture of dietary antioxidants, including L-selenomethionine (an aminoacid), vitamin C, vitamin E succinate, $\alpha$-lipoic acid (an organosulphur compound derived from octanoic acid), combined with $N$-acetyl-cysteine (an antioxidative drug and dietary supplement) has been found to protect hematopoietic cells and improve survival after its pre- or post-irradiation administration to X-irradiated mice [71] or post-irradiation administration to proton-irradiated mice [72].

Attention has also been paid to combinations of herbal extracts, e.g., Gupta and coworkers have shown potentiating effects of post-irradiation treatment with Picrorrhiza kurroa extract on pre-irradiation radioprotective efficacy of Podophyllum hexandrum extract [73]. Both the herbs are considered antioxidants, and Podophyllum hexandrum is also known for its anticancer effects.

An interesting report concerning radioprotective properties of the combination of selenium, zinc, and manganese with Lachesis muta (a pit viper species) venom in whole-body irradiated rats has been published by Crescenti and coworkers [74]. The authors call the combination an immunomodulator which positively affects radiosensitive tissues, including those of the gastrointestinal and hematopoietic systems [74].

Of additional interest are recent studies on pharmacological reduction of radiation-induced gastrointestinal toxicity by inhibitors of prolyl hydroxylase domain-containing enzymes (PHDs) whose administration has resulted in the stabilization of hypoxia-inducible factors (HIFs) protecting important cellular compartments from radiation-induced damage [75]. Combined administration of PHDs with glycogen synthase kinase-3 (GSK-3) inhibitors, decreasing the induction of p53-upregulated modulator of apoptosis (PUMA), has been proposed for radioprotection [76].

Chemical structures of selected substances explored in Section 3, namely dipyridamole, adenosine monophosphate, $N^{6}$-(3-iodobenzyl)adenosine-5'-N-methyluronamide, diclofenac, meloxicam, nandrolone decanoate, quercetin, indralin, genistein, captopril, tocopherol succinate, AMD3100, $\alpha$-tocopherol acetate, ascorbic acid, L-selenomethionine, $\alpha$-lipoic acid, and $N$-acetylcysteine, are summarized in Figure 2. 
<smiles>Nc1ncnc2c1ncn2[C@@H]1O[C@H](COP(=O)(O)O)[C@@H](O)[C@H]1O</smiles>

e) meloxicam

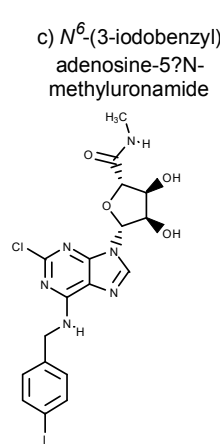

g) quercetin<smiles>O=C(O)Cc1ccccc1Nc1c(Cl)cccc1Cl</smiles>

h) indralin<smiles>CCCCCCCCC(=O)O[C@H]1CC[C@H]2[C@@H]3CCC4=C(CCC(=O)C4)[C@@H]3CC[C@@]12C</smiles>

$\begin{array}{lll}\text { i) genistein } & \text { j) captopril } & \text { k) tocopherol succinate }\end{array}$

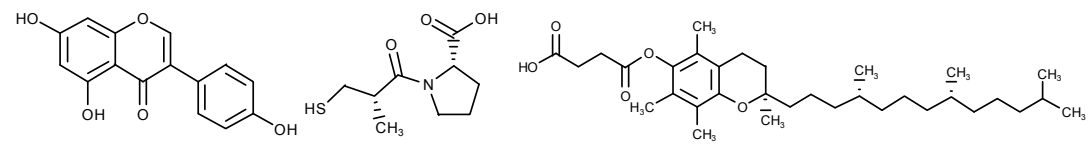

I) AMD3100

m) ?-tocopherol acetate<smiles>NCCCNCCCN(CCCNCCCNCCCNCCCN1CCCNCCC1)Cc1ccc(CNCCCN)cc1</smiles><smiles>CC(=O)Oc1c(C)c(C)c2c(c1C)CC[C@@](C)(CCC[C@H](C)CCC[C@H](C)CCCC(C)C)O2</smiles>

n) ascorbic acid

o) L-selenomethionine

p) ?-lipoic acid

q) N-acetylcysteine<smiles>O=C1O[C@H]([C@@H](O)CO)C(O)=C1O</smiles><smiles>N[C@@H](CS)C(=O)O</smiles><smiles>O=C(O)CCCC[C@@H]1CCSS1</smiles><smiles>CC(=O)N[C@@H](CS)C(=O)O</smiles>

Figure 2. Chemical structures of selected substances explored in Section 3.

Agents mentioned in this review that have been used in pharmacological combinations in attempts to modify the course of ARS are summarized in Table 1.

Table 1. Summary of agents tested in pharmacological combinations in attempts to modify the course of the acute radiation syndrome (ARS).

\begin{tabular}{|c|c|c|}
\hline Agent or Group of Agents & Predominant Radiomodifying Effect(s) & $\begin{array}{l}\text { Reference } \\
\text { Number(s) }\end{array}$ \\
\hline Adenosine monophosphate & $\begin{array}{l}\text { Stimulator of hematopoietic cell proliferation through } \\
\text { adenosine receptor action }\end{array}$ & [41-44] \\
\hline Alpha-lipoic acid & Antioxidant & {$[71,72]$} \\
\hline AMD3100 & Influences migration and homing of hematopoietic stem cells & {$[60]$} \\
\hline Amifostine & Free radical scavenger & [5-39] \\
\hline Ascorbic acid (vitamin C) & Antioxidant & [70-72] \\
\hline Beta-glucan & Immunomodulator, stimulator of hematopoiesis & {$[24-27,54]$} \\
\hline
\end{tabular}


Table 1. Cont.

\begin{tabular}{|c|c|c|}
\hline Agent or Group of Agents & Predominant Radiomodifying Effect(s) & $\begin{array}{l}\text { Reference } \\
\text { Number(s) }\end{array}$ \\
\hline Broncho-Vaxom & Immunomodulator, stimulator of hematopoiesis & {$[28,29]$} \\
\hline Captopril & Vasodilator & [68] \\
\hline Diclofenac & $\begin{array}{c}\text { Inhibitor of prostaglandin synthesis, stimulator of } \\
\text { myelopoiesis }\end{array}$ & [47-49] \\
\hline Dipyridamole & $\begin{array}{l}\text { Enhances adenosine receptor action, stimulator of } \\
\text { proliferation of hematopoietic cells }\end{array}$ & [41-44] \\
\hline Erythropoietin (EPO) & Hematopoietic growth factor, stimulator of erythropoiesis & {$[31,65,66]$} \\
\hline Flt3-ligand & Hematopoietic growth factor, stimulator of hematopoiesis & {$[62,63]$} \\
\hline Genistein & Antioxidant & [68] \\
\hline $\begin{array}{l}\text { Glycogen synthase kinase-3 (GSK-3) } \\
\text { inhibitor }\end{array}$ & Regulator of apoptosis & [76] \\
\hline $\begin{array}{l}\text { Granulocyte colony-stimulating factor } \\
\text { (G-CSF) }\end{array}$ & Hematopoietic growth factor, stimulator of hematopoiesis & $\begin{array}{l}{[30-38,52-54,56,58,} \\
\quad 61,63,65,66]\end{array}$ \\
\hline $\begin{array}{c}\text { Granulocyte-macrophage } \\
\text { colony-stimulating factor (GM-CSF) }\end{array}$ & Hematopoietic growth factor, stimulator of hematopoiesis & {$[57,60,66]$} \\
\hline Indralin & Adrenomimetic & [67] \\
\hline $\begin{array}{l}\text { Inhibitors of prolyl hydroxylase } \\
\text { domain-containing enzymes (PHDs) }\end{array}$ & Antioxidants & {$[75,76]$} \\
\hline Interleukin-1 (IL-1) & $\begin{array}{c}\text { Cytokine, regulator of immune response, inflammation, and } \\
\text { hematopoiesis }\end{array}$ & [55] \\
\hline Interleukin-3 (IL-3) & $\begin{array}{l}\text { Cytokine, regulator of production of granulocytes and } \\
\text { macrophages }\end{array}$ & {$[57,63,66]$} \\
\hline Interleukin-6 (IL-6) & Cytokine, stimulator of myelopoiesis & [56] \\
\hline Interleukin-11 (IL-11) & Cytokine, stimulator of hematopoiesis and lymphopoiesis & [30] \\
\hline Lachesis muta venom & Immunomodulator (?) & [74] \\
\hline $\begin{array}{l}\text { Megakaryocyte growth and development } \\
\text { factor (MGDF) }\end{array}$ & Hematopoietic growth factor, stimulator of thrombopoiesis & [61] \\
\hline Meloxicam & $\begin{array}{l}\text { Inhibitor of prostaglandin synthesis, stimulator of } \\
\text { myelopoiesis }\end{array}$ & [50-53] \\
\hline Metformin & Antioxidant, modulator of cell renewal & [39] \\
\hline $\begin{array}{c}N^{6} \text {-(3-iodobenzyl)adenosine- } 5^{\prime}- \\
N \text {-methyluronamide (IB-MECA) }\end{array}$ & $\begin{array}{l}\text { Stimulator of hematopoietic cell proliferation through } \\
\text { adenosine receptor action }\end{array}$ & {$[45,46,50,51]$} \\
\hline $\mathrm{N}$-acetyl-cysteine & Antioxidant & {$[71,72]$} \\
\hline Nandrolone decanoate & Anabolic effects & [65] \\
\hline Peptidoglycan & Immunomodulator, stimulator of hematopoiesis & [31] \\
\hline Picrorhiza kuroa extract & Antioxidant & [73] \\
\hline Podophyllum hexandrum extract & Antioxidant & [73] \\
\hline Polysaccharide from Sipunculus nudus & Immunomodulator, stimulator of hematopoiesis & [30] \\
\hline $\begin{array}{l}\text { Prostaglandin } \mathrm{E}_{2} \text { and prostaglandin family } \\
\text { members (misoprotol) }\end{array}$ & $\begin{array}{l}\text { Modulators of proliferation of hematopoietic cells, protectors } \\
\text { of intestinal tissue }\end{array}$ & [19-23] \\
\hline Quercetin & Antioxidant & [67] \\
\hline Romiplostim & Hematopoietic growth factor, stimulator of hematopoiesis & [65] \\
\hline $\begin{array}{l}\text { Salts of various metals (copper, manganese, } \\
\text { selenium, zinc) }\end{array}$ & Antioxidants & {$[10-14,71,72,74]$} \\
\hline $\begin{array}{l}\text { Stem cell factor (SCF) (c-kit ligand, mast cell } \\
\text { growth factor) }\end{array}$ & Hematopoietic growth factor, stimulator of hematopoiesis & {$[31,57,62,63,66]$} \\
\hline Stromal-derived factor-1 (SDF-1) & Chemokine, influences migration of hematopoietic cells & [62] \\
\hline Synthokine SC-55494 & Cytokine, stimulator of hematopoiesis & {$[58,59]$} \\
\hline Thrombopoietin (TPO) & Hematopoietic growth factor, stimulator of thrombopoiesis & {$[60,62]$} \\
\hline Tumor necrosis factor (TNF) & Modulator of inflammation & [55] \\
\hline Vitamin $\mathrm{E}$ and its family members & Antioxidants & {$[15-18,69-72]$} \\
\hline
\end{tabular}




\section{Discussion and Conclusions}

As follows from the above summary of the findings on pharmacological modulation of ARS by combined drug treatment, this topic has required long-term attention. It can be deduced from the literature that, whereas in the years of the Cold War researchers focused their studies predominantly on the evaluation of "true radioprotectors", i.e., chemical radioprotectors effective at pre-irradiation administration, current efforts are concentrated especially on compounds usable in therapeutic post-irradiation treatment approaches. Summaries of therapeutic principles for post-irradiation approaches to the treatment of ARS due to radiation accidents or contingent terrorist attacks can be found in several publications (e.g., [77,78]).

ARS is connected with multi-organ involvement, or even multi-organ failure [78]. Therefore, its general medical management is complex in essence and can comprise, e.g., administration of antibiotic, antimycotic, and antiviral substances (e.g., [79]), drugs for maintaining homeostasis through supporting renal function (e.g., [80]), transplantation of hematopoietic stem cells (e.g., [81]), or drugs modulating the course of the cutaneous radiation damage (e.g., [82]). These aspects of the treatment of the acute radiation disease exceed the thematic extent of this review and should be studied from other sources. This article has focused on pharmacological approaches directly influencing the radiation damage and those aimed preferentially at the hematopoietic radiation syndrome which represents the primary challenge in the case of whole-body acute exposure over 2 Gy [83].

As documented by the rich literature data, the aim of achieving a high efficacy of pharmacological reduction of the acute radiation damage in connection with a low toxicity of the therapy by means of combining suitable drugs has represented a challenge for a number of researchers over a long period. Many of the treatment schemes confirm the correctness of the idea; the values of important parameters after combined treatment are often additive or synergistic when compared to those following administration of the individual components of the combinations studied. According to the opinion of the authors of this review, the future of the research consists especially in studies on post-irradiation approaches which correspond more to the current dangers and demands in comparison with classical chemical radioprotectors set for pre-irradiation protective administration. Cytokines will undoubtedly remain the most efficacious component of the combined therapies of ARS. However, supplementation of the cytokine cocktails with some of the other drugs mentioned in this review would be worthy of study. Moreover, it should be taken into consideration that the most effective drug combination utilizing high doses of its individual components do not always represent the optimum general outcome. Development of effective combinations of radioprotectors/radiomitigators using doses of their components that are as low as possible, which would, thus, show the lowest possible intensities and incidences of their undesirable effects, might be the goal of some of the future studies on this topic. In this way, the aim of obtaining pharmacological approaches, which would be well tolerated in patients with ARS, could be achieved.

Acknowledgments: This work was supported by the Czech Science Foundation project 16-12454S, Ministry of Health of the Czech Republic (AZV grant no. 16-29835A; all rights reserved) and from the Czech Republic contribution to the Joint Institute for Nuclear Research, Dubna (Project of the Czech Plenipotentiary and the $3+3$ Project for 2015, 2016).

Author Contributions: M.H. designed the manuscript and significantly participated in its writing; Z.H. contributed to writing of Section 3 (Combinations without Amifostine); D.D. was significantly engaged in looking up and drawing chemical structures of selected radiomodifying substances; and M.F. contributed to writing of Section 2 (Combinations including Amifostine).

Conflicts of Interest: The authors declare no conflict of interest.

\section{References}

1. Singh, V.K.; Romaine, P.L.P.; Newman, V.L.; Seed, T.M. Medical countermeasures for unwanted CBRN exposures. Part II radiological and nuclear threats with review of recent countermeasure patents. Expert Opin. Ther. Pat. 2016, 26, 1399-1408. [CrossRef] [PubMed] 
2. Singh, V.K.; Romaine, P.L.P.; Seed, T.M. Medical countermeasures for radiation exposure and related injuries: Characterization of medicines, FDA-approval status and inclusion into the strategic national stockpile. Health Phys. 2015, 108, 607-630. [CrossRef] [PubMed]

3. Pellmar, T.C.; Rockwell, S. The Radiological/Nuclear Threat Countermeasures Working Group. Priority list of research areas for radiological nuclear threat countermeasures. Radiat. Res. 2005, 163, 115-123. [CrossRef] [PubMed]

4. Weiss, J.F.; Kumar, K.S.; Walden, T.L.; Neta, R.; Landauer, M.R.; Clark, E.P. Advances in radioprotection through the use of combined agent regimens. Int. J. Radiat. Biol. 1990, 57, 709-722. [CrossRef] [PubMed]

5. Hosseinimehr, S.A. Trends in development of radioprotective agents. Drug Discov. Today 2007, 12, 794-805. [CrossRef] [PubMed]

6. Brown, D.G.; Pittock, J.W.; Rubinstein, J.S. Early results of the screening program for radioprotectors. J. Radiat. Oncol. Biol. Phys. 1982, 8, 565-570. [CrossRef]

7. Buschini, A.; Aneschi, E.; Carlo-Stella, C.; Regazzi, E.; Rizzoli, V.; Poli, P.; Rossi, C. Amifostine (WR-2721) selective protection against melphalan toxicity. Leukemia 2000, 14, 1642-1651. [CrossRef] [PubMed]

8. Buschini, A.; Aneschi, E.; Carlo-Stella, C.; Regazzi, E.; Rizzoli, V.; Poli, P.; Rossi, C. Bleomycin genotoxicity and amifostine (WR-2721) cell protection in normal leukocytes vs. K562 tumoral cells. Biochem. Pharmacol. 2002, 63, 967-975. [CrossRef]

9. Hofer, M.; Falk, M.; Komůrková, D.; Falková, I.; Bačíková, A.; Klejdus, B.; Pagáčová, E.; Štefančíková, L.; Weiterová, L.; Angelis, K.J.; et al. Two new faces of amifostine: Protector from DNA damage in normal cells and inhibitor of DNA repair in cancer cells. J. Med. Chem. 2016, 59, 3003-3017. [CrossRef] [PubMed]

10. Weiss, J.F.; Hoover, R.L.; Kumar, K.S. Selenium pretreatment enhances the radioprotective effect and reduces the lethal toxicity of WR-2721. Free Radic. Res. Commun. 1987, 3, 33-38. [CrossRef] [PubMed]

11. Brown, D.Q.; Graham, W.J.; MacKenzie, L.J.; Pittock, J.W.; Shaw, L.M. Can WR-2721 be improved upon? Pharmacol. Ther. 1988, 39, 157-168. [CrossRef]

12. Kumar, K.S.; Vaishnav, Y.N.; Weiss, J.F. Radioprotection by antioxidant enzymes and enzyme mimetics. Pharmacol. Ther. 1988, 39, 301-309. [CrossRef]

13. Buntzel, J.; Micke, O.; Mucke, R.; Glatzel, M.; Schonekaes, K.G.; Schafer, U.; Kisters, K.; Bruns, F. Amifostine and selenium during simultaneous radiochemotherapy in head and neck cancer-Redox status data. Trace Elem. Electrol. 2005, 22, 211-2015. [CrossRef]

14. Ali, B.H.; Al Moundhri, M.S. Agents ameliorating or augmenting the nephrotoxicity of cisplatin and other platinum compounds: A review of some recent research. Food Chem. Toxicol. 2006, 44, 1173-1183. [CrossRef] [PubMed]

15. Weiss, J.F.; Landauer, M.R. Radioprotection by antioxidants. Ann. N. Y. Acad. Sci. 2000, 899, 44-60. [CrossRef] [PubMed]

16. Srinivasan, V.; Weiss, J.F. Radioprotection by vitamin-E-injectable vitamin-E administered alone or with WR-3689 enhances survival of irradiated mice. Int. J. Radiat. Oncol. Biol. Phys. 1992, 23, 841-845. [CrossRef]

17. Kaplan, B.; Orhan, O.; Yazici, C.; Karahacioglu, E. Radioprotective effects of amifostine (WR 2721) and vitamin E on whole-body-irradiated rat liver. Turk. Klin. Tip Bilim. Derg. 2009, 29, 1055-1062.

18. Singh, V.K.; Fatanmi, O.O.; Wise, S.Y.; Newman, V.L.; Romaine, P.L.; Seed, T.M. Potentiation of the radioprotective efficacy of two medical countermeasures, gamma-tocotrienol and amifostine, by a combination prophylactic modality. Radiat. Prot. Dosim. 2016, 172, 302-310. [CrossRef] [PubMed]

19. Hanson, W.R. Radioprotection of murine intestine by WR-2721, 16,16-dimethyl-prostaglandin $E_{2}$ and the combination of both agents. Radiat. Res. 1987, 111, 361-373. [CrossRef] [PubMed]

20. Lu, L.; Pelus, L.M.; Broxmeyer, H.E. Modulation of expression of HLA-DR (Ia) antigens and the proliferation of human erythroid (BFU-E) and multipotential (CFU-GEMM) progenitor cells by prostaglandin E. Exp. Hematol. 1984, 12, 741-748. [PubMed]

21. Hoggatt, J.; Singh, P.; Sampath, J.; Pelus, L.M. Prostaglandin $E_{2}$ enhances hematopoietic stem cell homing, survival, and proliferation. Blood 2009, 113, 5444-5455. [CrossRef] [PubMed]

22. Hanson, W.R.; Houseman, K.A.; Collins, P.W. Radiation protection in vivo by prostaglandins and related compounds of the arachidonic acid cascade. Pharmacol. Ther. 1988, 39, 347-356. [CrossRef] 
23. Mota, J.M.S.C.; Soares, P.M.G.; Menezes, A.A.J.; Lemos, H.P.; Cunha, F.Q.; Brito, G.A.C.; Ribeiro, R.A.; de Souza, M.H.L.P. Amifostine (Wr-2721) prevents indomethacin-induced gastric damage in rats: Role of non-protein sulfhydryl groups and leukocyte adherence. Dig. Dis. Sci. 2007, 52, 119-125. [CrossRef] [PubMed]

24. Patchen, M.L.; MacVittie, T.J.; Jackson, W.E. Postirradiation glucan administration enhances the radioprotective effects of WR-2721. Radiat. Res. 1989, 117, 59-69. [CrossRef] [PubMed]

25. Patchen, M.L.; MacVittie, T.J.; Weiss, J.F. Combined modality radioprotection: The use of glucan and selenium with WR-2721. Int. J. Radiat. Oncol. Biol. Phys. 1990, 18, 1069-1075. [CrossRef]

26. Pillai, T.G.; Devi, P.U. Mushroom beta glucan: Potential candidate for post irradiation protection. Mutat. Res. Genet. Toxicol. Environ. 2013, 751, 109-115. [CrossRef] [PubMed]

27. Hofer, M.; Pospíšil, M. Modulation of animal and human hematopoiesis by $\beta$-glucans. A review. Molecules 2011, 16, 7969-7979. [CrossRef] [PubMed]

28. Macková, N.O.; Fedoročko, P. Combined radioprotective effect of Broncho-Vaxom ${ }^{\circledR}$ and WR-2721 on hematopoiesis and circulating blood-cells. Neoplasma 1995, 42, 25-30. [PubMed]

29. Fedoročko, P.; Brezáni, P.; Macková, N.P. Radioprotective effects of WR-2721, Broncho-Vaxom ${ }^{\circledR}$ and their combinations-Survival, myelopoietic restoration and induction of colony-stimulating activity in mice. Int. J. Immunopharmacol. 1994, 16, 177-184. [CrossRef]

30. Jiang, S.Q.; Shen, X.R.; Liu, Y.M.; He, Y.; Jiang, D.W.; Chen, W. Radioprotective effects of Sinpulus nudus L. polysaccharide combined with WR-2721, rhIL-11 and rhG-CSF on radiation-injured mice. J. Radiat. Res. 2015, 56, 515-522. [CrossRef] [PubMed]

31. Liu, W.; Chen, Q.; Wu, S.; Xia, X.C.; Wu, A.Q.; Cui, F.M.; Gu, Y.P.; Zhang, X.G.; Cao, J.P. Radioprotector WR-2721 and mitigating peptidoglycan synergistically promote mouse survival through the amelioration of intestinal and bone marrow damage. J. Radiat. Res. 2015, 56, 278-286. [CrossRef] [PubMed]

32. Nagata, S. The Cytokine Handbook; Thomson, A., Ed.; Academic Press: New York, NY, USA, 1994; p. 371.

33. Drouet, M.; Delaunay, C.; Grenier, N.; Garrigou, P.; Mayol, J.F.; Hérodin, F. Cytokines in combination to treat radiation-induced myelosuppression: Evaluation of SCF + glycosylated EPO + pegylated G-CSF as an emergency treatment in highly irradiated monkeys. Haematol. Hematol. J. 2008, 93, 465-466. [CrossRef] [PubMed]

34. Hofer, M.; Pospíšil, M.; Komůrková, D.; Hoferová, Z. Granulocyte colony-stimulating factor in the treatment of acute radiation syndrome: A concise review. Molecules 2014, 19, 4770-4778. [CrossRef] [PubMed]

35. Patchen, M.L.; MacVittie, T.J.; Souza, L.M. Postirradiation treatment with granulocyte colony-stimulating factor and preirradiation WR-2721 administration synergize to enhance hematopoietic recostitution and increase survival. Int. J. Radiat. Oncol. Biol. Phys. 1992, 22, 773-779. [CrossRef]

36. Patchen, M.L. Amifostine plus granulocyte colony-stimulating factor therapy enhances recovery from supralethal radiation exposures-Preclinical experience in animal-models. Eur. J. Cancer 1995, 31A, S17-S21. [CrossRef]

37. Neumeister, P.; Jaeger, G.; Eibl, M.; Sormann, S.; Zinke, W.; Linkesch, W. Amifostine in combination with erythropoietin and G-CSF promotes multilineage hematopoiesis in patients with myelodysplastic syndrome. Leuk. Lymphoma 2001, 40, 345-349. [CrossRef] [PubMed]

38. Winczura, P.; Jassem, J. Combined treatment with cytoprotective agents and radiotherapy. Cancer Treat. Rev. 2010, 36, 268-275. [CrossRef] [PubMed]

39. Miller, R.C.; Murley, J.S.; Grdina, D.J. Metformin exhibits radiation countermeasures efficacy when used alone or in combination with sulfhydryl containing drugs. Radiat. Res. 2014, 181, 464-470. [CrossRef] [PubMed]

40. Zucali, J.R. Mechanisms of protection of hematopoietic stem-cells from irradiation. Leuk. Lymphoma 1994, 13, 27-32. [CrossRef] [PubMed]

41. Pospíšil, M.; Hofer, M.; Netíková, J.; Pipalová, I.; Vacek, A.; Bartoníčková, A.; Volenec, K. Elevation of extracellular adenosine induces radioprotective effects in mice. Radiat. Res. 1995, 134, 323-330. [CrossRef]

42. Hofer, M.; Pospisil, M.; Weiterova, L.; Hoferova, Z. The role of adenosine receptor agonists in regulation of hematopoiesis. Molecules 2011, 16, 675-685. [CrossRef] [PubMed]

43. Pospíšil, M.; Hofer, M.; Znojil, V.; Vácha, J.; Netíková, J.; Holá, J. Synergistic effect of granulocyte colony-stimulating factor and drugs elevating extracellular adenosine on neutrophil production in mice. Blood 1995, 86, 3692-3697. [PubMed] 
44. Pospíšil, M.; Hofer, M.; Znojil, V.; Netíková, J.; Vácha, J.; Holá, J.; Vacek, A. Granulocyte colony-stimulating factor and drugs elevating extracellular adenosine synergize to enhance the haemopoietic reconstitution in irradiated mice. Eur. J. Haematol. 1998, 60, 172-180. [CrossRef] [PubMed]

45. Bar-Yehuda, S.; Madi, L.; Barak, D.; Mittelman, M.; Ardon, E.; Ochaion, A.; Cohn, S.; Fishman, P. Agonists to the $\mathrm{A}_{3}$ adenosine receptor induce G-CSF production via NF-kappa B activation: A new class of myeloprotective agents. Exp. Hematol. 2002, 30, 1390-1398. [CrossRef]

46. Hofer, M.; Pospíšil, M.; Šefc, L.; Dušek, L.; Vacek, A.; Holá, J.; Hoferová, Z.; Štreitová, D. Activation of adenosine $\mathrm{A}_{3}$ receptors supports hematopoiesis-stimulating effects of granulocyte colony-stimulating factor in sublethally irradiated mice. Int. J. Radiat. Biol. 2010, 86, 649-656. [CrossRef] [PubMed]

47. Hofer, M.; Pospíšil, M.; Hoferová, Z.; Weiterová, L.; Komůrková, D. Stimulatory action of cyclooxygenase inhibitors on hematopoiesis. A review. Molecules 2012, 17, 5615-5625. [CrossRef] [PubMed]

48. Pospíšil, M.; Hofer, M.; Pipalová, I.; Viklická, Š. Enhancement of hematopoietic recovery in gamma-irradiated mice by the joint use of diclofenac, an inhibitor of prostaglandin production, and glucan, a macrophage activator. Exp. Hematol. 1992, 20, 891-895. [PubMed]

49. Hofer, M.; Pospíšil, M.; Viklická, Š.; Vacek, A.; Pipalová, I.; Bartoníčková, A. Hematopoietic recovery in repeatedly irradiated mice can be enhanced by a repeatedly administered combination of diclofenac and glucan. J. Leukoc. Biol. 1993, 53, 185-189. [PubMed]

50. Hofer, M.; Pospíšil, M.; Dušek, L.; Hoferová, Z.; Weiterová, L. Inhibition of cyclooxygenase-2 promotes the stimulatory action of adenosine $\mathrm{A}_{3}$ receptor agonist on hematopoiesis in sublethally $\gamma$-irradiated mice. Biomed. Pharmacother. 2011, 65, 427-431. [CrossRef] [PubMed]

51. Hofer, M.; Pospíšil, M.; Dušek, L.; Hoferová, Z.; Komůrková, D. Agonist of the adenosine $\mathrm{A}_{3}$ receptor, IB-MECA, and inhibitor of cyclooxygenase-2, meloxicam, given alone or in a combination early after total body irradiation, enhance survival of $\gamma$-irradiated mice. Radiat. Environ. Biophys. 2014, 53, 211-215. [CrossRef] [PubMed]

52. Hofer, M.; Pospíšil, M.; Holá, J.; Vacek, A.; Štreitová, D.; Znojil, V. Inhibition of cyclooxygenase 2 in mice increases production of G-CSF and induces radioprotection. Radiat. Res. 2008, 170, 566-571. [CrossRef] [PubMed]

53. Hofer, M.; Pospíšil, M.; Znojil, V.; Holá, J.; Vacek, A.; Štreitová, D. Meloxicam, a cyclooxygenase-2 inhibitor, increases the level of serum G-CSF and might be usable as an auxiliary means in G-CSF therapy. Physiol. Res. 2008, 57, 307-310. [PubMed]

54. Patchen, M.L.; MacVittie, T.J.; Solberg, B.D.; Souza, L.M. Survival enhancement and hemopoietic regeneration following radiation exposure: Therapeutic approach using glucan and granulocyte colony-stimulating factor. Exp. Hematol. 1990, 18, 1042-1048. [PubMed]

55. Neta, R.; Oppenheim, J.J.; Douches, S.D. Interdependence of the radioprotective effects of human recombinant interleukin $1 \alpha$, tumor necrosis factor $\alpha$, granulocyte colony-stimulating factor, and murine recombinant granulocy-macrophage colony-stimulating factor. J. Immunol. 1988, 140, 108-111. [PubMed]

56. Patchen, M.L.; Fischer, R.; MacVittie, T.J. Effects of combined administration of interleukin-6 and granulocyte colony-stimulating factor on recovery from radiation-induced hemopoietic aplasia. Exp. Hematol. 1993, 21, 338-344. [PubMed]

57. Patchen, M.L.; Fischer, R.; MacVittie, T.J.; Seiler, F.R.; Williams, D.E. Mast cell growth factor (C-kit ligand) in combination with granulocyte-macrophage colony-stimulating factor and interleukin-3: In vivo hemopoietic effects in irradiated mice compared to in vitro effects. Biotherapy 1993, 7, 13-26. [CrossRef] [PubMed]

58. Farese, A.M.; Hérodin, F.; McKearn, J.P.; Baum, C.; Burton, E.; MacVittie, T.J. Acceleration of hematopoietic reconstitution with a synthetic cytokine (SC-55494) after radiation-induced bone marrow aplasia. Blood 1996, 87, 581-591. [PubMed]

59. MacVittie, T.J.; Farese, A.M.; Hérodin, F.; Grab, L.B.; Baum, C.M.; McKearn, J.P. Combination therapy for radiation-induced bone marrow aplasia in nonhuman primates using synthokine SC-55494 and recombinant human granulocyte colony-stimulating factor. Blood 1996, 87, 4129-4135. [PubMed]

60. Neelis, K.J.; Hartong, S.C.; Egeland, T.; Thomas, G.R.; Eaton, D.L.; Wagemaker, G. The efficacy of single-dose administeration of thrombopoietin with coadministration of either granulocyte/macrophage colony-stimulating factor or granulocyte colony-stimulating factor in myelosuppressed rhesus monkeys. Blood 1997, 90, 2565-2573. [PubMed] 
61. Farese, A.M.; Hunt, P.; Grab, L.B.; MacVittie, T.J. Combined administration of recombinant human megakaryocyte growth and development factor and granulocyte colony-stimulating factor enhances multilineage hematopoietic reconstitution in nonhuman primates after radiation-induced marrow aplasia. J. Clin. Investig. 1996, 97, 2145-2151. [CrossRef] [PubMed]

62. Hérodin, F.; Bourin, P.; Mayol, J.F.; Lataillade, J.J.; Drouet, M. Short-term injection of antiapoptotic cytokine combinations soon after lethal gamma-irradiation promotes survival. Blood 2003, 101, 2609-2616. [CrossRef] [PubMed]

63. Hérodin, F.; Roy, L.; Grenier, N.; Delaunay, C.; Bauge, S.; Vaurijoux, A.; Gregoire, E.; Martin, C.; Alonso, A.; Mayol, L.F.; et al. Antiapoptotic cytokines in combination with pegfilgrastim soon after irradiation mitigate myelosuppression in nonhuman primates exposed to high radiation dose. Exp. Hematol. 2007, 35, 1172-1181. [CrossRef] [PubMed]

64. Hérodin, F.; Drouet, M. Myeloprotection following cytotoxic damage: The sooner the better. Exp. Hematol. 2008, 36, 769-770. [CrossRef] [PubMed]

65. Hirouchi, T.; Ito, K.; Nakano, M.; Monzen, S.; Yoshino, H.; Chiba, M.; Hazawa, M.; Nakano, A.; Ishikawa, J.; Yamaguchi, M.; et al. Mitigative effects of a combination of multiple pharmaceutical drugs on the survival of mice exposed to lethal ionizing radiation. Curr. Pharm. Biotechnol. 2016, 17, 190-199. [CrossRef]

66. Singh, V.K.; Newman, V.L.; Seed, T.M. Colony-stimulating factors for the treatment of the hematopoietic compartment of the acute radiation syndrome (H-ARS): A review. Cytokine 2015, 71, 22-37. [CrossRef] [PubMed]

67. Vasin, M.V.; Ushakov, I.B.; Kovtun, V.I.; Komarova, S.N.; Semenova, L.A.; Koroleva, L.V.; Galkin, A.A. The influence of combined application of quercetin and indralin on post-irradiation repair of hematopoiesis in acute radiation injury. Radiat. Biol. Radioecol. 2011, 51, 247-251. (in Russian)

68. Day, R.M.; Davis, T.A.; Barshishat-Kupper, M.; McCart, E.A.; Tipton, A.S.; Landauer, M.R. Enhanced hematopoietic protection from radiation by the combination of genistein and captopril. Int. Immunopharmac. 2013, 15, 348-356. [CrossRef] [PubMed]

69. Singh, V.K.; Wise, S.Y.; Fatanmi, O.O.; Beattie, L.A.; Ducey, E.J.; Seed, T.M. Alpha tocopherol succinate- and AMD3100-mobilized progenitors mitigate radiation combined injury in mice. J. Radiat. Res. 2014, 55, 41-53. [CrossRef] [PubMed]

70. Vasil'eva, I.N.; Bespalov, V.G.; Baranenko, D.A. Radioprotective and apoptotic properties of a combination of alpha-tocopherol acetate and ascorbic acid. Bull. Exp. Biol. Med. 2016, 161, 248-251. [CrossRef] [PubMed]

71. Wambi, C.; Sanzari, J.; Wan, X.S.; Nuth, M.; Davis, J.; Ko, Y.H.; Sayers, C.M.; Baran, M.; Ware, J.H.; Kennedy, A.R. Dietary antioxidants protect hematopoietic cells and improve animal survival after total-body irradiation. Radiat. Res. 2008, 169, 384-396. [CrossRef] [PubMed]

72. Wambi, C.O.; Sanzari, J.K.; Sayers, C.M.; Nuth, M.; Zhou, Z.Z.; Davis, J.; Finnberg, N.; Lewis-Wambi, J.S.; Ware, J.H.; El-Deiry, W.S.; et al. Protective effects of dietary antioxidants on proton total-body irradiation-mediated hematopoietic cell and animal survival. Radiat. Res. 2009, 172, 175-186. [CrossRef] [PubMed]

73. Gupta, M.L; Sankwar, S.; Verma, S.; Devi, M.; Samanta, N.; Agarwala, P.K.; Kumar, R.; Singh, P.K. Whole-body protection to lethally irradiated mice by oral administration of semipurified fraction of Podophyllum hexandrum and post irradiation treatment with Picorrhiza kurroa. Tokai J. Exp. Clin. Med. 2008, 33, 6-12. [PubMed]

74. Crescenti, E.J.V.; Medina, V.A.; Croci, M.; Sambuco, L.A.; Prestifilippo, J.P.; Elverdin, J.C.; Bergoc, R.M.; Rivera, E.S. Radioprotection of sensitive rat tissues by oligoelements Se, Zn, Mn plus Lachesis muta venom. J. Radiat. Res. 2011, 52, 557-567. [CrossRef] [PubMed]

75. Taniguchi, C.M.; Miao, Y.R.; Diep, A.N.; Wu, C.; Rankin, E.B.; Atwood, T.F.; Xing, L.; Giaccia, A.J. PHD inhibition mitigates and protects against radiation-induced gastrointestinal toxicity via HIF2. Sci. Transl. Med. 2014, 6, 236ra64. [CrossRef] [PubMed]

76. Olcina, M.M.; Giaccia, A.J. Reducing radiation-induced gastrointestinal toxicity - the role of the PHD/HIF axis. J. Clin. Investig. 2016, 126, 3708-3715. [CrossRef] [PubMed]

77. Moulder, J.E. Post-irradiation approaches to treatment of radiation injuries in the context of radiological terrorism and radiation accidents. Int. J. Radiat. Biol. 2004, 80, 3-10. [CrossRef] [PubMed]

78. Dörr, H.; Meineke, V. Acute radiation syndrome caused by accidental radiation exposure-Therapeutic principles. BMC Med. 2011, 9, 126. [CrossRef] [PubMed] 
79. Waselenko, J.K.; MacVittie, TJ.; Blakely, W.F.; Pesik, N.; Wiley, A.L.; Dickerson, W.E.; Tsu, H.; Confer, D.L.; Coleman, C.N.; Seed, T.; et al. Strategic National Stockpile Radiation Working Group: Medical management of the acute radiation syndrome: Recommendations of the Strategic National Stockpile Radiation Working Group. Ann. Intern. Med. 2004, 140, 1037-1051. [CrossRef] [PubMed]

80. Moulder, J.E.; Cohen, E.P. Radiation-induced multi-organ involvement and failure: The contribution of radiation effects on the renal system. Br. J. Radiol. 2005, 27 (Suppl. 2005), 82-88. [CrossRef]

81. Dainiak, N.; Ricks, R.C. The evolving role of haematopoietic stem cell transplantation in radiation injury: Potentials and limitations. Br. J. Radiol. 2005, 27 (Suppl. 2005), 169-174. [CrossRef]

82. Dainiak, N.; Gent, R.N.; Carr, Z.; Schneider, R.; Bader, R.; Buglova, E.; Chao, N.; Coleman, C.N.; Ganser, A.; Gorin, C.; et al. Literature review and global consensus on management of acute radiation syndrome affecting non-hematopoietic organs systems. Disaster Med. Public Health Prep. 2011, 5, 183-201. [CrossRef] [PubMed]

83. Drouet, M.; Hérodin, F. Radiation victim management and the haematologist in the future: Time to revisit therapeutic guidelines? Int. J. Radiat. Biol. 2010, 86, 636-648. [CrossRef] [PubMed]

(C) 2017 by the authors. Licensee MDPI, Basel, Switzerland. This article is an open access article distributed under the terms and conditions of the Creative Commons Attribution (CC BY) license (http://creativecommons.org/licenses/by/4.0/). 